\title{
Interactive comment on "Variational regional inverse modeling of reactive species emissions with PYVAR-CHIMERE' by Audrey Fortems-Cheiney et al.
}

Audrey Fortems-Cheiney et al.

audrey.fortems@Isce.ipsl.fr

Received and published: 29 April 2020

The comment was uploaded in the form of a supplement: https://www.geosci-model-dev-discuss.net/gmd-2019-186/gmd-2019-186-AC3supplement.pdf

Interactive comment on Geosci. Model Dev. Discuss., https://doi.org/10.5194/gmd-2019-186, 2019. 